\title{
Problems and Options of Integrated Water Resources Management in Nigeria: Administrative Constraints and Policy Strategies
}

\author{
H. O. Nwankwoala \\ Department of Geology, College of Natural and Applied Sciences, University of Port Harcourt, Nigeria \\ E-mail address: nwankwoala_ho@yahoo.com
}

\begin{abstract}
Nigeria has greater challenges when it comes to water development and management. The current water resources development and supply status is unacceptably low and needs a major transformation. With the rapid growth in population, urbanization, industrialization and competition for economic development, water resource has become vulnerable to depletion and degradation. Management of this valuable resource is determined by its acceptability and utilization in terms of quantity and quality. Due to imbalance between demand and availability, management approaches are facing various ethical dilemas. This paper therefore considers the water supply and sanitation situation in the country and the challenges facing the sector. The paper calls for institutional reforms and review of policy targets, define key elements for the development of action and investment plans as well as provide some guidelines in order to minimize duplication and maximize effectiveness. The paper also suggested strategies and viable framework/agenda for sustainable water supply and emphasizes that the machinery of water resources development and management needs an urgent overhauling with the aim of streamlining the overlapping functions of the various agencies that have operated the system up till now. More importantly, the paper suggested integrated approaches/strategies for sustainable management as well as offers relevant policy recommendations for water resources management in Nigeria.
\end{abstract}

Keywords: water resources management; water policy; sustainability; water utilization; Nigeria

\section{INTRODUCTION}

Nigeria is located on the west coast of Africa, between latitudes $4^{\circ} \mathrm{N}$ and $14^{\circ} \mathrm{N}$ and between longitudes $2^{\circ} \mathrm{E}$ and $15^{\circ} \mathrm{E}$. The land area is approximately $925,000 \mathrm{~km}^{2}$, with abundant water resources, enough to cater for the needs of her teeming population of about 140 million (NPC, 2006).

Nigeria has six hydrological basins covering the far low-lying swamp forest south, the flat dense rain forest, hilly shrub lands in the middle belt, relatively flat savannah grasslands in the north, and semi-arid areas in the far-north (Akpabio, 2012b). Average rainfall for the country varies between about $250 \mathrm{~mm}$ per year in the north (occurring mostly around April and September) and could be as high as $4000 \mathrm{~mm}$ per year in the south (occurring mostly around March through October) depending on location. Nigeria has two major river systems 
namely, the river Niger (entering the country from the northwest) and river Benue (entering from northeast). The two rivers meet at Lokoja, then move in a southern direction into an extensive delta before discharging into the Atlantic Ocean while other rivers flow directly into the Ocean or lake Chad. Many rivers in the north are intermittent, having water in them only in the rainy season while the greatest number of the rivers in the south are perennial, flowing all year round, and are important sources of drinking and irrigation water.

Given the nature of the hydrogeology of Nigeria (about $60 \%$ of the country is believed to be underlain by crystalline rocks, $20 \%$ by consolidated sedimentary materials and $20 \%$ by unconsolidated sedimentary materials), static water levels in water wells range between zero in parts of the coastal alluvium to 200 metres in some sedimentary areas (Schoeneich, 2003; FGN, 2000). It is further established that in crystalline rock areas found in many parts of the north, well yields are unpredictable; where sufficient depth of weathering exists the area may be suitable for operation (minimum yield of 10 litres per minute), but only at specific localities where deep weathering and underlying fractures coincide and yields likely to be sufficient for motorized schemes.

Nigeria's surface water resources is estimated at to be about 267 billion $\mathrm{m}^{3}$ /annum while its groundwater resource is estimated at about 52 billion $\mathrm{m}^{3}$ of groundwater potential. While only $15 \%$ of the surface water has been utilized (ADB, 2007), statistics on the actual amount of groundwater utilization is, however, not available. What is most commonly known is that groundwater resources (which come in the form of boreholes and hand dug wells) have become the most important sources of public and private water in urban and rural areas which attract wide and minimally regulated exploitation.

Despite the huge water resources, water resources development has not been able to keep pace with the phenomenal population growth (Oteze, 2006). With rising population, water resources represent a major prerequisite and driver of socio-economic development. Economic sectors that water caters for include domestic, agriculture and fisheries, industry, recreation, municipality including waste/effluent disposal, and water transportation. It also plays a prominent role in power and energy generation: hydroelectric power generation's share of total power production has decreased from over $70 \%$ in 2004 to the present proportion of about $40 \%$ (Oyebande, 2004). Yet, at the same time, population and economic growth have led to ever more demands on the resources. This paper therefore, attempts to identify the impediments and associated requirements for, and a path towards, long-term sustainable water use and management in Nigeria.

\section{HISTORICAL REVIEW OF WATER RESOURCES DEVELOPMENT IN NIGERIA}

At the global scene, there has been continuing efforts in respect of sustainable management of water resources. The Earth Summit, the World Water Commission, the World Water Forum as well as other water related projects of Global Water Partnership, World Bank, WHO, UNESCO, FAO, UNICEF and UNDP etc have been at the forefront in the timely efforts of water resources management in Nigeria, especially in the provision of safe drinking water and basic sanitation which is within the frameworks of the United Nations Millennium Development Goals (MDGs).

In the early 1950s, government's attempt at water development in Nigeria was through the Geological Survey of Nigeria. But concerted efforts have been made since independence towards the provision of potable water to the citizenry. The Nigerian government's major 
intervention in water resources development came during the first National Development Plan (1962-1968) which saw the establishment of the River Niger and Lake Chad Basin Commissions. In 1973 and 1974, the Sokoto-Rima and Chad Basin Authorities were established. In 1976, the river basin authorities were increased to 11 to cover the whole country. But, before then in 1975, the Federal Ministry of Water Resources (FMWR) was created. Following the creation of the ministry, extensive water resources development (both surface and groundwater) was embarked upon to boost economic activities such as irrigation, fisheries as well as hydropower generation.

More importantly, all these giant strides were aimed at improving water supply delivery in line with the United Nation's International Drinking Water Supply and Sanitation Decade (IDWSSD, 1981-1990). Aside from these noble efforts, the Federal Government embarked upon other numerous intervention programmes in the water sector, including the National Borehole Project (1980), Department of Food, Roads, and Rural Infrastructure (DFRRI) (1986-1994), The Petroleum (Special) Trust Fund (PTF) Rural Water Supply Project (19951999), Improved National Access to Water Supply (1999) and lastly the Senate Constituency Water Projects (2001 till date).

\section{WATER RESOURCES MANAGEMENT IN NIGERIA: EMERGING REALITIES, ISSUES AND TRENDS}

The haphazard historical development common to developing countries had led so far to a highly fragmented water supply sector and poor achievement in Nigeria. The Federal Government has been in the forefront in the efforts towards the water supply sector through the provision of matching grants to various state governments in the late 70s. Although, the Federal Government can no longer afford to provide such grants, it has continued to provide some form of administrative framework and guidance for orienting water supply in the country. In spite of these elegant postures, suitable machinery for the effective management of water resources has not yet evolved.

This is because the authorities have put up institutions for this purpose, but at the same time set up rival agencies to carry out very overlapping functions. Responsibility for water supply is therefore thinly spread over several governmental departments giving rooms for a gross overlap of responsibility (Fig. 1). The overall implication is waste of available resources, leading to lack of progress in water management.

The trends and issues to non-attainment of adequate water resources management and emerging scenarios in Nigeria include: scientific and technological deficit, institutional inertia, vested interests and corruption, amongst others, to be highlighted and addressed later in this paper. As a result of weak service delivery, Nigerians do not even see the need for payment of water rate, even where water is provided. Since water is an economic good, some cost recovery is expected from services that are provided, at least to cover the cost of operations and maintenance. The MDGs vision will only be achieved if everybody concerned keeps to the cost sharing formula for water supply projects. 


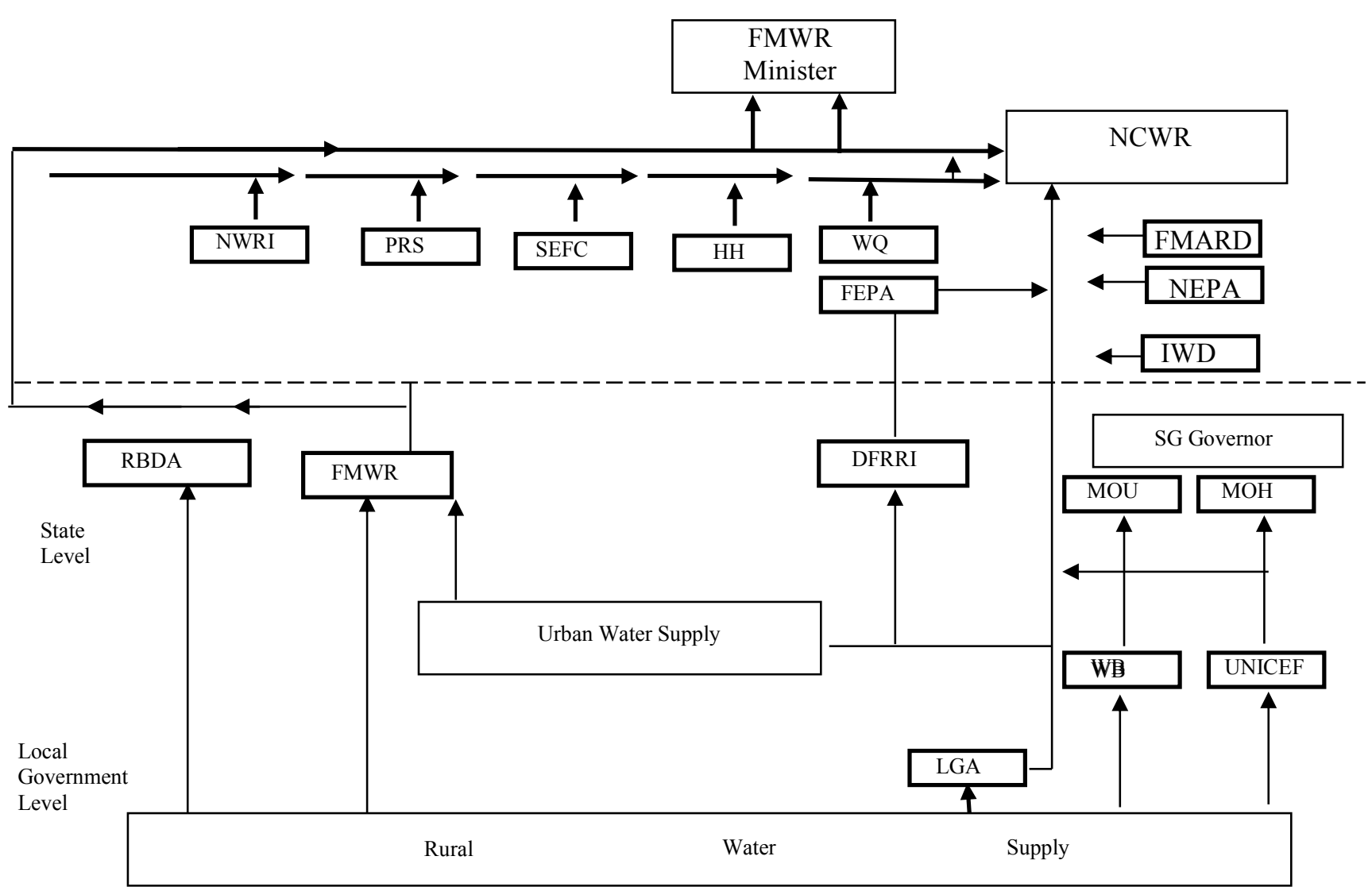

Fig. 1. Schematic Representation of Present Organization of Water Resources Management in Nigeria.

\section{LEGEND}

FMWR $=$ Fed. Min. of Water Resources

NWRI = National Water Resources Institute

PRS = Planning, Research \& Statistics

$\mathrm{SEFC}=$ Soil Erosion/Flood Control

$\mathrm{HH}=$ Hydrogeology \& Hydrology

WQ = Water Quality

NCWR = National Council on Water Resources

RBDA = River Basin Dev. Authority

IWD = Inland Waterways Dept.
$\mathrm{SG}=$ State Governments

MOU $=$ Min. of Utilities

$\mathrm{MOH}=$ Min. of Health

WB = Water Boards

LGA = Local Govt. Area

FEPA $=$ Fed. Env. Prot. Agency

ADP $=$ Agric. Dev. Project

\section{ACCESSIBILITY OF WATER SUPPLY AND SANITATION IN NIGERIA}

Improving access to water supply and sanitation in Nigeria is hampered by geographical, socio-economic and institutional factors (Akpabio, 2012a). Geographically, there is a huge regional and local disparity between the north and south as well as urban and rural areas as presented from different sources. Figures estimated by WHO/UNICEF (2010), NBS (2007), and reported by Onabolu et al (2011) indicate that $72 \%$ of urban dwellers to 47 $\%$ of the rural population have access to improved water sources; while the ratio of water access to sanitation is only $2: 1$ that is $58 \%$ water access to $26 \%$ sanitation (WHO/UNICEF, 2010). Regionally, the north central (NC), north eastern (NE), and north western (NW) zones of Nigeria have improved drinking water access of $52.2 \%, 27.3 \%, 42.5 \%$, respectively 
compared to $72.7 \%$ and $54.1 \%$ in the south western (SW) and south eastern (SE) zones, respectively. On the other hand, $29 \%, 34.4 \%, 34.1 \%$ representing the NC, NE NW respectively use improved sanitation in comparison to $55.5 \%$ and $55.0 \%$ in SE and SW zones, respectively (NBS, 2007). The data agrees to the fact that some regions and areas (SW, NW and urban areas) are relatively better off than others in access to water supply and sanitation (Akpabio, 2012a). On the other hand, some regions (SE and SS) curiously fare relatively better in sanitation over water supplies than others (Table 2).

Table 2. Evaluation of Regional Indicators and Access to Water and Sanitation Related Services (Source: Akpabio, 2012a).

\begin{tabular}{|c|c|c|c|c|c|c|c|c|c|}
\hline Indicators & NE & NW & NC & SE & SW & SS & National & Rural & Urban \\
\hline Safe water source (\%) & 30.7 & 50.64 & 48.9 & 40.8 & 73.5 & 45.9 & 51.4 & 40.4 & 73.4 \\
\hline Safe sanitation (\%) & 45.4 & 61.6 & 46.6 & 69.5 & 62.1 & 55.0 & 57.6 & 47.6 & 77.0 \\
\hline $\begin{array}{c}\text { Improved waste disposal } \\
(\%)\end{array}$ & 6.2 & 10.7 & 8.8 & 9.0 & 36.0 & 13.2 & 16.1 & 4.8 & 37.9 \\
\hline Incidence of diarrhea (\%) & 5.5 & 4.8 & 5.5 & 5.7 & 4.1 & 4.1 & 4.9 & 5.1 & 4.3 \\
\hline $\begin{array}{c}\text { Water treatment before } \\
\text { drinking (\%) }\end{array}$ & 4.6 & 7.5 & 14.1 & 11.4 & 20.4 & 5.8 & 11.3 & 14.5 & 9.7 \\
\hline Health access (\%) & 48.4 & 55.3 & 61.1 & 37.1 & 73.1 & 45.9 & 55.1 & 47.8 & 70.9 \\
\hline Poverty incidence (\%) & 72.2 & 71.2 & 67.0 & 26.7 & 43.0 & 35.1 & 54.4 & 63.3 & 43.2 \\
\hline
\end{tabular}

\section{IMPEDIMENTS TO SUSTAINABLE WATER RESOURCES MANAGEMENT IN NIGERIA: MAJOR ISSUES AND TRENDS}

In Nigeria, suitable machinery for the effective and sustainable management of water resources has not yet evolved. This is because the authorities have put up institutions for this purpose, but at the same time set up rival agencies to carry out very overlapping functions. The overall implication is waste of available resources, leading to lack of progress in water development and management. Generally, the Nigerian water problem revolves round two critical issues, namely:

(i) Inadequate access/poor distribution of water resources in time and space in relation to the needs of the people and

(ii) Inadequate planning and management of these resources.

The above mentioned problems have further manifested themselves in the form of incessant water shortages, poor access to public water supply and water-borne diseases, poor environmental quality causing water pollution, improper or partial distribution of public wells due to lack of water well statistics and favouritism, poor maintenance and often sabotage in the development and operational process of public wells, and proliferation of shallow private/commercial wells of poor standard by individuals who are financially less capable of standard wells drilled with adequate drilling tools. 
According to Ajayi, et al., (2003); Ajayi, (2006); Akujieze, et al (2003); Ezeibgo, (2003); Goni, (2006); Hanidu, (1990, 2003); Nwankwoala \& Mmom (2006); Nwankwoala \& Mmom, (2008); Nwankwoala, (2009); Nwankwoala (2011); Nwaogazie, (1995); Offodile, (2003, 2006); Oyebande, (2006); Oteze, (2006) and Tijani, (2006), the major obstacles for sound water management include: absence of or ineffective legal/institutional and regulatory framework, poor maintenance culture, poor technical and institutional capacity, lack of coordination, multiple programmes, lack of data and information for planning, shortage of well-trained/committed manpower with appropriate local technology, irregular recruitment and limited manpower occasioned by the civil- service structure and the over-bearing bureaucratic control by supervising ministries, lack of professional input on water programmes and projects, absence of professionalism due to politicization, career stagnation and the lure of private practice, lack of community participation and inadequate revenue generation by water agencies, inadequate funding as shown by poor budget allocations, irregular disbursements of subventions, limited sources of aids and grants (particularly from foreign sources), inappropriate infrastructures as well as lack of adequate quality monitoring and evaluation.

In Nigeria, for instance, data on groundwater levels are not widely published or made available outside government organizations. Extraction and recharge estimates are also unreliable. As a result, discussions on groundwater over-exploitation and depletion are always based on unrealistic data. However, it is a fact that falling water tables and depletion of economically accessible groundwater reserves will have serious socio-economic consequences in a country like Nigeria. Therefore, it is needless to point out that there is an urgent need for conservation of this vital resource for sustainable development and management.

In the light of the foregoing, it is highly likely that the future expansion in water will continue to take place in Nigeria. This is primarily due to the relatively high population growth rate, combined with the unprecedented rise in industrialization and welfare, which tends to increase the average per capita water use. The largest single consumer of water is, and will continue to be agriculture with urban and industrial uses on the rise. Though the generalizations made here may not be totally justified, as differences exist in different parts of the country.

Current water use is characterized, as earlier noted, by uncoordinated development and supply to all sectors: rural and urban users, small and large scale users, industrial and agricultural users. This, in part, is attributable to the intrinsic properties of the resource. The general prevalence and stability in time and space of groundwater, for instance, makes it a reliable and widely-accessible resource, easily amenable to private, local, and on - demand exploitation. Therefore, options/strategies for significant improvements in water supply are in the areas of formulation of adequate, efficient and effective water policies, funding/appropriate infrastructures as well as monitoring and evaluation. Beyond these, other useful and practical national and local level initiatives towards solving the water and sanitation problems in Nigeria (Nwankwoala, 2011; Akpabio, 2012b) should border on: (a) sustaining massive public investment in water and sanitation infrastructures; (b) less politicization of relevant water and sanitation programmes; (c) less excessive attention to technological approaches and more attention to adequate local level participation and involvement; (d) maintenance of comprehensive data on need areas as well as sustaining a culture of post-project evaluation to determine programme success levels. 


\section{APPROACHES TO SUSTAINABLE WATER MANAGEMENT IN NIGERIA}

Because water supply is on the concurrent legislative list in the constitution and that means all tiers of government have responsibilities for the provision of water supply to the people. Realizing the significant role played by potable water supply and clean environment in ensuring good and healthy individual, family and communal lives, government has embarked on certain policies and strategies to improve the coverage level of rural water supply and sanitation facilities. The water supply is to ensure that all Nigerians have access to clean water and sanitation at an affordable price. The viable options/solution to the Nigerian water problem is a unified and integrated approach to water resources planning and the provision of reliable information on the following:

(i) The nature and magnitude of available water resources

(ii) The future demand for water for domestic, agricultural and industrial purposes

(iii) How these demands can be faithfully met within the ambit of available resources.

The issues raised above can be adequately addressed through groundwater resources mapping. Not only can the information be obtained at regular intervals but their accurate state, can also be updated. In this context, efficient water policy is imperative if sustainable water utilization is to be realized. Water management policies therefore, will need to address a multitude of issues including, but not restricted to the following:

(i) Management of supplies to improve water availability in time and space

(ii) Management of demands including efficiency of water use, sectoral interaction with economic activities etc.

(iii) Balancing competing demands and preservation of the integrity of water dependent ecosystem.

Aside from the above mentioned water management options, there is need for the following:

(i) encourage user participation in the water resources administration

(ii) propose and coordinate actions geared towards the protection, defense and knowledge on water use

(iii) proper coordination between the different tiers of government and the public, realistic tariff structure to cover cost of services, research into local production of materials required in the water sector, training of professionals and education of the public about water conservation

(iv) promote, organize, participate and undertake all kinds of activities, courses and seminars, outreach programmes, training, and specialization on water, and any other relevant collaboration with different public administrations.

For an effective management of water resources, there is a need to create awareness among the different user groups and workout area specific plans for sustainable development. Thus, sustainable water management not only requires proper assessment of available resources and understanding of the interconnection between surface and groundwater system, but also actions required for proper resource management and prevention of the adverse effects of uncontrolled development of water resources (Velayutham,1999). The component 
of action-driven water policy must be to consider and manage water as an economic as well as social good, and importantly, to manage water at the lowest appropriate level with users involved in the planning and implementation stages (Fig. 2).

Capacity development defined as the process by which individuals, organizations, institutions and societies develop abilities to perform functions, solve problems and set and achieve objectives (Lopes and Theisohn, 2003); includes elements of developing competent human resources, providing sound institutional capacity and the creation of enabling environment. Fig. 3 illustrates the levels, activities, outputs and goals of capacity building. In the developed nations, it was possible to couple large investments in infrastructures with capacity development and knowledge building. Unfortunately, this is not the case in a developing country like Nigeria where financial resources represent a major constraint.

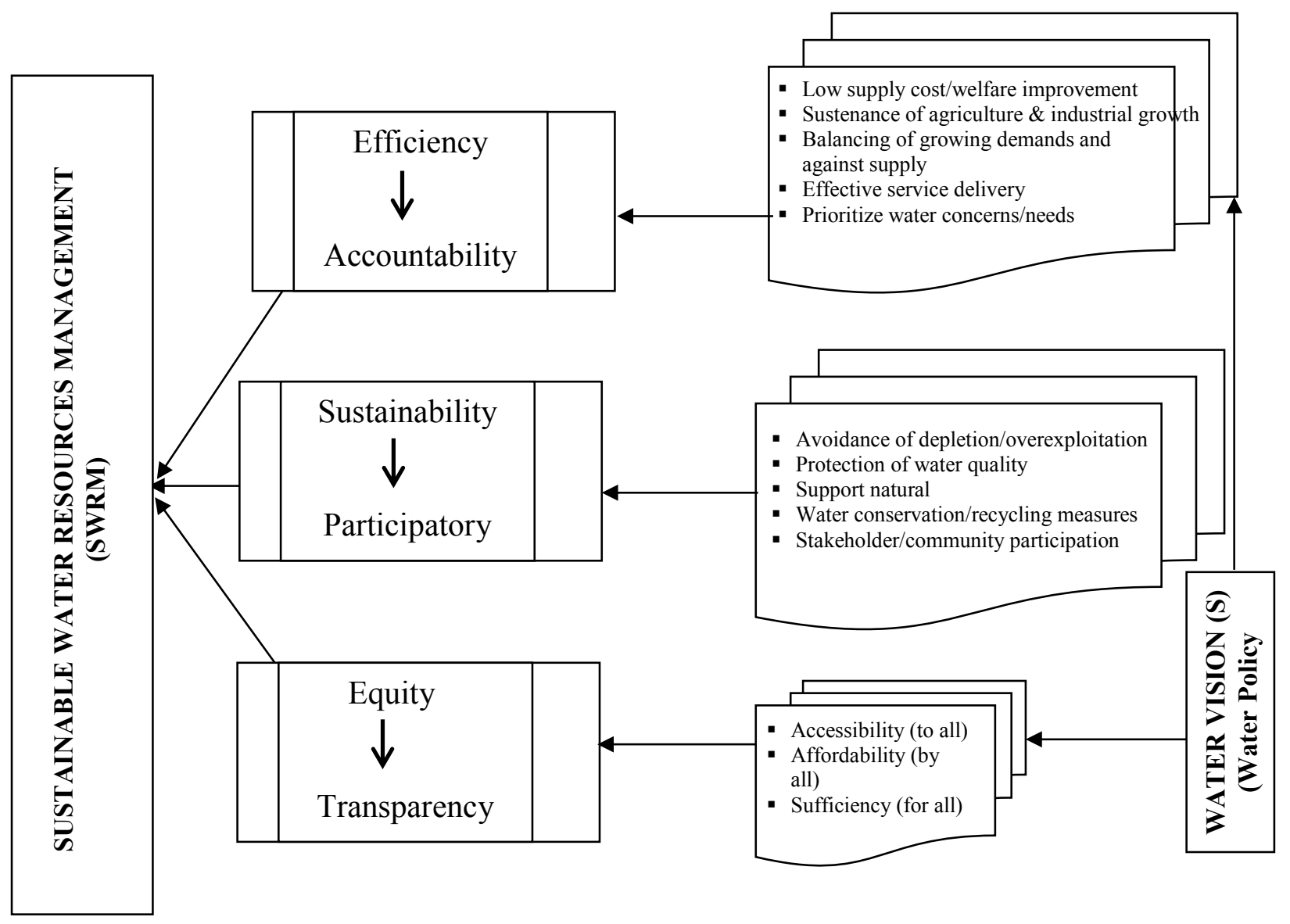

Fig. 2. Components of action-driven water policy \& sustainable water resources Management (modified after Arntzen, 1999).

More specifically, there is an urgent need to check the contamination level of water resources. The water protection from contamination/ pollution can be ensured by several ways, as enumerated by (Menon, 1998; Nwankwoala and Udom, 2008), summarized as follows: 
(i) Restricting the disposal of industrial discharges to the ground in vulnerable areas through introduction of discharge permits and appropriate charges to encourage recycling and reduction.

(ii) Inventory of aquifers, their characteristics and classification

(iii) Preparation of vulnerability maps, based on distribution of travel times, chemical parameters, types of topsoil, subsoil and landuse

(iv) Control of groundwater withdrawals

(v) Delineating and prioritizing areas of high groundwater vulnerability for main sewerage extension.

(vi) Effective enforcement provisions for water protection regulations.

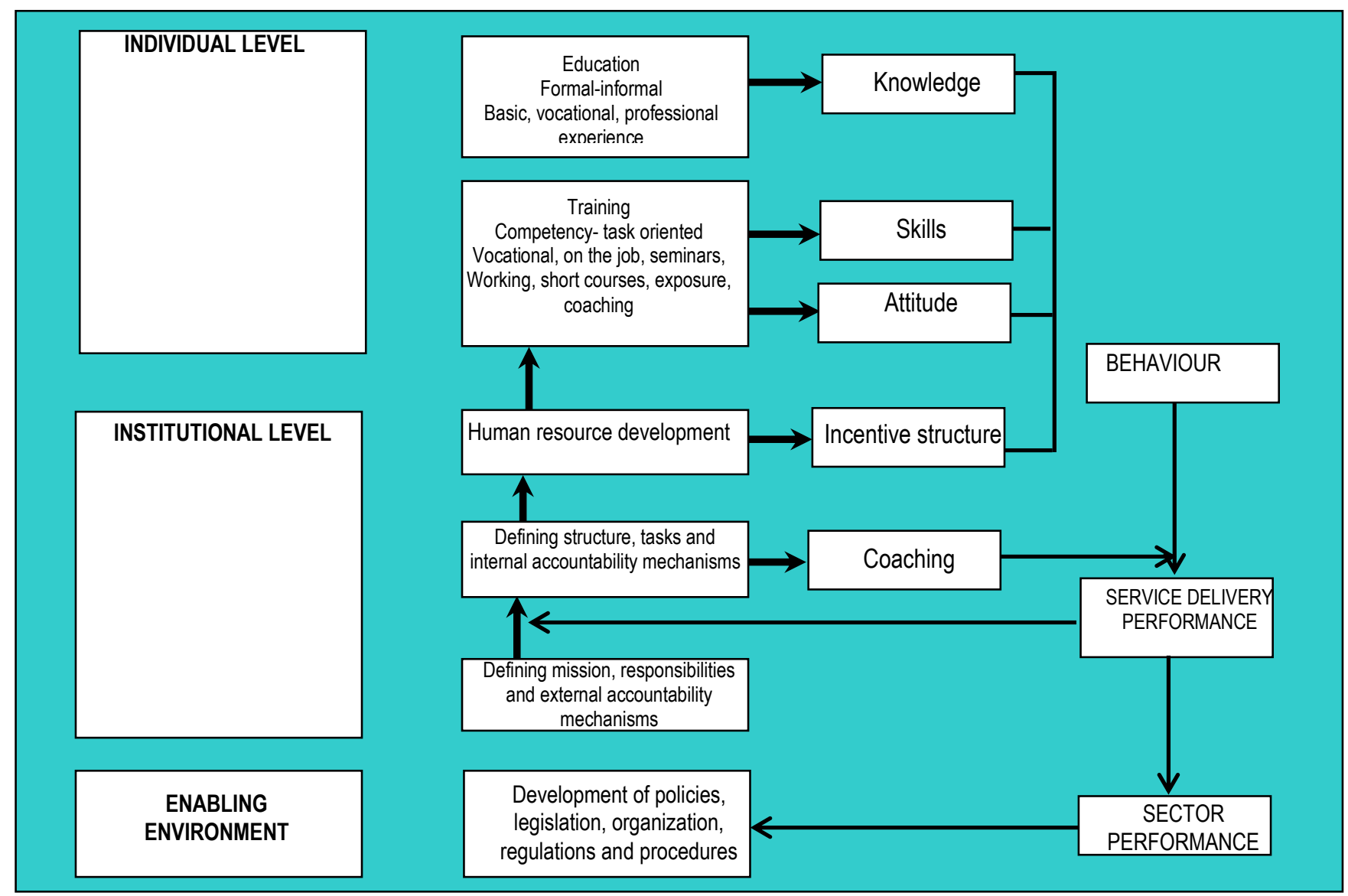

Fig. 3. Capacity Development: Levels, Activities, Outputs and Goals, (Source: United Nation World Water Development Report, No 2.).

If the Millennium Development Goals (MDGs) formulated by the United Nations, designed to halve the number of people without access to safe drinking water by the year 2015 , is to be attained, then all stakeholders - government, scientists, water managers, community leaders, Corporate Organizations, NGOs, CBOs, and others should begin to recognize that there is a distinct need for better data and better utilization of that data. These needs, though, generally exceed, most times the financial capacity to effectively address them, efforts must be intensified for improvement. Additionally, federal, states and local 
governments support must be garnered to address wide - reaching technological and research needs vital to developing the best possible science and water management strategies that keep pace with water resources. This is very imperative because, with business as usual, Millennium Development Goals will not be met. Therefore, the challenge is to communicate to decision makers and legislators that presently available information must be significantly enhanced to accomplish sustainability goals. Particularly, fundamental data, on-going programmes, data standards, data coordination and sharing and regional aquifer characterization are core requirements for more effective management.

\section{INSTITUTIONAL PERSPECTIVES}

The National Water Policy in Nigeria is the development of the water resources potentials of the country in order to ensure the availability, equitable distribution and conservation of water for domestic and industrial uses, food production, navigation, hydropower, and recreational activities etc. Global concerns with the increased use of water for domestic, agriculture and industrial purposes and the associated problems of sustainability and resource depletion has necessitated renewed attention towards issues of water resources governance. In doing so, direct regulation through timely and adequate policies have been advocated.

Generally, given that access to water is a universal and constitutionally guaranteed right, providing water supplies and sanitation services has always been at the core of public duty and responsibility to the population (Akpabio, 2012b). In consequence, numerous versions of public water supply and sanitation policies have been evolved by the government of Nigeria over the years (Table 3 ).

Table 3. Relevant Water and Sanitation Policies in Nigeria (Akpabio, 2012b).

\begin{tabular}{|c|c|}
\hline Policy Title & Key Provision \\
\hline National Policy on Environment, 1989 & $\begin{array}{l}\text { Focuses on water quality regulation and standard as well } \\
\text { as pollution control. }\end{array}$ \\
\hline $\begin{array}{l}\text { National Rural Water Supply and Sanitation } \\
\text { Policy, } 2000\end{array}$ & $\begin{array}{c}\text { Focuses specifically on rural water and sanitation } \\
\text { through community participation. The programme } \\
\text { targets were to increase water coverage from } 43 \% \text { to } 80 \\
\% \text { by } 2010 \text { and } 100 \% \text { by } 2015 \text {. The sanitation coverage } \\
\text { was to be increased from } 32 \% \text { to } 60 \% \text { by } 2010 \text { and } 90 \\
\% \text { by } 2015 .\end{array}$ \\
\hline $\begin{array}{l}\text { National Water Resources Management Policy, } \\
2003\end{array}$ & $\begin{array}{l}\text { This recognizes water as an economic good, opted for } \\
\text { integrated and demand-driven services. }\end{array}$ \\
\hline National Water and Sanitation Policy, 2004 & $\begin{array}{l}\text { This operated strictly in line with the demand-driven } \\
\text { approach of the National Water Resources Policy. }\end{array}$ \\
\hline $\begin{array}{l}\text { National Environmental Sanitation Policy } \\
\text { (NESP), } 2005\end{array}$ & $\begin{array}{l}\text { A bit comprehensive as it touched on a range of issues } \\
\text { including solid waste, medical waste, excreta waste, } \\
\text { sewage management, food sanitation and hygiene, } \\
\text { sanitation at public places, adequate potable water } \\
\text { supply, urban drainage management and hygiene } \\
\text { education etc. }\end{array}$ \\
\hline & his attempted to address water and sanitation issues i \\
\hline
\end{tabular}


National Economic Empowerment and Development Strategy NEEDS (2003-2007)

National Development Plan (NDP), 2007 clearly defined spatial units namely, urban areas, small towns, rural areas. NEEDS placed high priority on the development of safe and adequate water supply and sanitation services as a key instrument for fighting poverty and accelerating socio-economic development.

As one of the seven point development agenda of the Late Yar a dua's administration, targeted subsidies on water and sanitation facilities were planned for the poor.

\section{CONCLUSIONS AND WAY FORWARD}

For a sustainable water management, there should be effective policy framework. For any water scheme to succeed, the stakeholders must be involved, motivated and trained. Thus, taking into account all the constraints related to proper management and protection of water source vis-a vis action needed to be taken at different levels, a multi-pronged integrated approach with a well-conceived mix of professional, technical, administrative and legal steps and community participation would pave the way for achieving the need for laying a proper/strong ecological foundation for ensuring sustainable management of water resources in Nigeria.

The contents of individual policies over the last 20 years reflect several international policy and paradigmatic trend (Akpabio, 2012a) such as integrated water resources management (IWRM), water privatization and differences between water and sanitation. There is the need for the participation of all stakeholders to contribute and participate at different levels in order to achieve water for all in the shortest possible time.

To this effect, the future of understanding and taking appropriate actions on water resources management, in line with emerging international water policies (UN-Agenda 21, 1992), should involve integrated and coordinated efforts of all stakeholders. There is a need to build up a momentum with significant impact and credibility, and to avoid repetition and duplication of efforts. Hence, it is essential that data collection, monitoring and any dynamic modeling takes place continuously and on longer time scale to be able to detect and document effects of water degradation and conversely show the effects of remedial activities, despite the superimposition on natural climatic variability. Documentation, storage and dissemination of knowledge are important. Through the development of awareness, knowledge and capacity at the national and local level, it is envisioned that the overall knowledge gap will diminish- a step towards sustainable development and management of water resources.

\section{References}

[1] ADB (2007) Nigeria: Rural water supply and sanitation sub-programmes in Yobe and Osun States, appraisal report. Water and Sanitation Department (OWAS). May 2007.

[2] Ajayi J. O., Journal of Mining and Geology 42(1) (2006) 4150.

[3] Ajayi J. O., Sonuga F. A., Aliboh O. P., Oloke D. A. (2003). Sustainable potable water supply to Nigerians through conjunctive development of surface and groundwater resources, In: A.A Elueze (ed.) Contributions of Geoscienes and Mining to National Development, (NMGS) pp. 9-17. 
[4] Akpabio E. M. (a), Journal of Water, Sanitation and Hygiene for Development. 02(3) (2012) 168-181.

[5] Akpabio E. M. (b)(2012). Water Supply and Sanitation Services in Nigeria: The Policy Trend and Practice Constraints. Centre for Development Research (ZEF) Working Paper Series 96, July 2012, University of Bonn, Germany.

[6] Akujieze C. N., Coker S. J. L., Oteze G. E., Hydrogeology Journal 11 (2003) 259-274.

[7] Arntzen J. (1999). Sustainable water management in Southern Africa: An integrated perspective. In: J.H.C Gash, E.O. Odada, L. Oyebande and R.E. Schulze (eds.): Freshwater Resources in Africa. Proceeding of a workshop, Nairobi Kenya, pp. 81-87.

[8] Ezeigbo H. I. (2003). Towards sustainable potable water supply to Nigerians in the New Millennium. In: A.A Elueze (ed.) Contributions of Geosciences and Mining to National Development, (NMGS), pp. 19-21.

[9] FGN (2000). National Water Supply and Sanitation Policy. Department of Water Supply and Quality Control, Federal Ministry of Water Resources. Federal Republic of Nigeria.

[10] FMWRRD (1995). The study on the National Water Resources Master Plan. Japan International Cooperation (JICA) and Federal Ministry of Water Resources and Rural Development, Federal Republic of Nigeria, Abuja.

[11] Goni I. B., Journal of Mining and Geology 42(1) (2006) 51-55.

[12] Hanidu J. A., Water Resources Journal of the Nigerian Association of Hydrogeologists 1 (1990) 1-6.

[13] Hanidu J. A. (2003). Provision of potable water supplies to rural communities in Nigeria. Contributions of Geosciences and Mining to National Development, In: A.A Elueze (ed.), pp. 23-25.

[14] Menon S. (1998). Groundwater management: need for sustainable approach.

Proceedings of the seminar on Artificial Recharge of Groundwater, December, 1998, Central Groundwater Board, Ministry of Water Resources, New Delhi, www.wikipedia.org

[15] NATIONAL BUREAU OF STATISTICS (NBS) (2007). The multiple indicator cluster survey 2007. National Bureau of Statistics, Abuja, Nigeria

[16] NPC (2006). Census. National Population Commission, Nigeria

[17] Nwankwoala H. O., Mmom P. C., Journal of Nigerian Environmental Society 3(3) (2006) 204-214.

[18] Nwankwoala H. O., Mmom P. C., Journal of Nigerian Environmental Society 4(3) (2008) 34-42.

[19] Nwankwoala H. O., Udom G. J., Global Journal of Geological Sciences 6(2) (2008) 153-156.

[20] Nwankwoala H. O., Water Resources Journal of the Nigerian Association of Hydrogeologists 19 (2009) 63-68.

[21] Nwankwoala H. O., African Journal of Environmental Science and Technology 5(13) (2011) 1170-1176. 
[22] Nwankwoala H. O., Mmom P. C. Journal of Nigerian Environmental Society 4(3) (2008) $34-42$.

[23] Nwaogzie I. L. (1995). Water resources development in Nigeria. Global outlook? Proceedings of the 8th Annual Conference on Environmental Considerations in Water Resources Development, Nigerian Association of Hydrogeologists held in Port Harcourt, Nigeria, Nov. 19-23, 1995.

[24] Offodile M. E. (1979). Water resources policy. Working paper on policy on Nigeria's water resources development, Unpublished paper from the Chairman of the Nigerian Mining and Geosciences Society Committee on water resources policy.

[25] Offodile M. E. (2003). The development and management of groundwater in Nigeria. In: A.A Elueze (ed.) Contributions of Geosciences and Mining to National Development, (NMGS), pp. 1- 7.

[26] Offodile M. E., Journal of Mining and Geology 42(1) (2006) 57-61.

[27] Onabolu B. O. D., Jimoh S. B., Igboroi M. K. C., Strihar G., Onyinlo A. G.,Iiya R., Physics and Chemistry of the Earth 36 (2011) 1189-1196.

[28] Oteze G. E., Journal of Mining and Geology 42(1) (2006) 15-20.

[29] Oyebande L., International Journal of Hydropower and Dams 6 (2004) 213-219.

[30] Oyebande L., Journal of Mining and Geology 42 (1) (2006) 21-30.

[31] Schoeneich K. (2003). Water Resources Administration in Nigeria. Paper Presented at the $39^{\text {th }}$ Annual International Conference of the Nigeria mining and Geosciences Society, "Itakpe 2003" Kogi State, $2^{\text {nd }}-8^{\text {th }}$ March, 2003.

[32] Tijani Min, Journal of Mining and Geology 42(1) (2006) 31-40.

[33] UN/WWAP (UNITED NATIONS/ WORLD WATER ASSESSMENT PROGRAMME) (2003). UN World Water Development Report: Water for people, water for life. UNESCO (United Nations Educational, Scientific and Cultural Organization) and Berghahn Books, Paris, New York and Oxford.

[34] UNICEF (2010). At a glance: Nigeria.

http://www.unicef.org/infobycountry/ nigeria_statistics.html

[35] Velayutham M. (1999). 50 years of natural resource management research. In: G.B Singh and B.R. Sharma (eds). The citizen's fifth report: state of India's environment, Part -11 Statistical Database, Centre for Science and Environment, New Delhi.

[36] WHO (2010.) UN- water global annual assessment of sanitation and drinking water (GLASS) 2010: targeting resources for better results, Geneva: World Health Organization.

[37] WHO/UNICEF (2010). Joint monitoring programme for water supply and sanitation. Meeting the MDG drinking water and sanitation target: mid-term assessment of progress. WHO; Geneva: UNICEF, New York.

[38] Ebad Bashiri, Jahanbakhsh Bashiri, Farhad Karimi, International Letters of Natural Sciences 3 (2013) 7-20.

[39] A. N. Obilonu, C. Chijioke, W. E. Igwegbe, O. I. Ibearugbulem, Y. F. Abubakar, International Letters of Natural Sciences 4 (2013) 44-53. 
[40] F. W. Owa, International Letters of Natural Sciences 3 (2014) 1-6.

[41] Sajid Qurashi, Omprakash Sahu, International Letters of Natural Sciences 5 (2014) $35-44$.

[42] Omprakash Sahu, International Letters of Natural Sciences 7 (2014) 35-43.

[43] Omprakash Sahu, International Letters of Natural Sciences 8(1) (2014) 1-8. 